DOI 10.35220/2078-8916-2020-37-3-30-35

УДК 616.314.17-008.1:579.84: 616.31-085:613.84: $616.33-002.2$

О.Л. Золотухіна, Ю.Г. Романова, д. мед. н. *С.А. Шнайдер, д. мед. $\boldsymbol{н}$.

Одеський національний медичний університет

*Державна установа «Інститут стоматології та щелепно-лицевої хірургії

Національної академії медичних наук України»

\section{ХАРАКТЕРИСТИКА ЗМІН МІКРОФЛОРИ \\ ПАРОДОНТАЛЬНИХ КИШЕНЬ ПІСЛЯ КОМПЛЕКСНОГО ЛІКУВАННЯ ТЮТЮНОЗАЛЕЖНИХ ПАЦІЕНТІВ 3 ХРОНІЧНИМ ГЕНЕРАЛІЗОВАНИМ ПАРОДОНТИТОМ НА ТЛІ ХРОНІЧНОГО ГІПЕРАЦИДНОГО ГАСТРИТУ}

На сьогоднішній день запально-дистрофічні захворювання пародонта, які розвиваються на тлі факторів ризику та супутньої соматичної патологї̈, залишаються актуальною невирішеною проблемою сучасної стоматологіï.

Мета роботи. Охарактеризувати зміни мікрофлори пародонтальних кишень після комплексного лікування тютюнозалежних пацієнтів з хронічним генералізованим пародонтитом на тлі хронічного гіперацииного гастриту.

Матеріали та методи. Було обстежено 90 пацієнтів (чоловіків і жінок) віком від 25 до 44 років, які були розподілені на 3 групи: перша група - 48 пацієнтів, хворих на хронічний генералізований пародонтит (ХГП) на тлі хронічного гіперацидного гастриту (ХГГ), асоиійованого з Helicobacter pylori, зі стажем тютюнопаління 5-7 років $і$ кількістю викурених цицарок від 15 до 20 на добу; друга група - 22 пацієнта, які хворі на ХГП та ХГГ, асоиійований з Helicobacter pylori, але без шкідлвої звички; третя група - контрольна, складалася з 20 здорових осіб.

Пацієнти-куриі були рандомно розподілені на дві підгрупи в залежності від запропонованої схеми лікування: пацієнтам першої підгрупи (1.1) була застосована базова терапія ХГП та запропонований лікувальнопрофілактичний комплекс (ЛПК) (процедури ультрафонофорезу з розробленим гелем «Апісан», пробіотичний препарат місцевого застосування - БіоГая ПроДентіс та ангіопротекторний препарат - Детралекс); пацієнтам другої підгрупи (1.2) застосовували базову терапію захворювань пародонта та процедури ультрафонофорезу з плацебо. 3 метою оцінки мікробіоценозу пародонтальних і ясенних кишень було проведено молекулярно-генетичне дослідження кількісного визначення пародонтопатогенів та якісного визначення орального Helicobacter pylori.

Результати дослідження. Застосування лікувальнопрофілактичного комплексу у тютюнозалежних хворих та пацієнтів без шкідливої звички з ХГП та ХГГ, aсоційованого з Helicobacter pylori, показало позитивну кількісну та видову редукиію пародонтопатогенних мікроорганізмів, а також зменшення поширенос- ті оральної інфекції Helicobacter pylori у даної категорії хворих.

Висновки. Отримані результати ПЛР-аналізу після лікування дозволили встановити ефективність ЛПК у тютюнозалежних пацієнтів та пацієнтів, які не палять, хворих на ХГП початкового, I ступеня на тлі кислотозалежних захворювань шлунку. Запропонований ЛПК продемонстрував елімінаційні властивості щодо пародонтопатогенних бактерій та орального Helicobacter pylori, щзо дозволяє нам рекомендувати ЛПК для використання в комплексному лікуванні ХГП на тлі факторів ризику.

Ключові слова: пародонтит, пародонтопатогени, гастрит, тютюнопаління.

\section{Е.Л. Золотухина, Ю.Г. Романова, *С. А. Шнайдер}

Одесский национальный медицинский университет *Государственное учреждение «Институт стоматологии и челюстно-лицевой хирургии Национальной академии медицинских наук Украины»

\section{ХАРАКТЕРИСТИКА ИЗМЕНЕНИЙ МИКРОФЛОРЫ ПАРОДОНТАЛЬНЫХ КАРМАНОВ ПОСЛЕ КОМПЛЕКСНОГО ЛЕЧЕНИЯ ТАБАКОЗАВИСИМЫХ ПАЦИЕНТОВ С ХРОНИЧЕСКИМ ГЕНЕРАЛИЗОВАННЫМ ПАРОДОНТИТОМ НА ФОНЕ ХРОНИЧЕСКОГО ГИПЕРАЦИДНОГО ГАСТРИТА}

На сегодняшний день воспалительно-дистрофические заболевания пародонта, которые развиваются на фоне факторов риска и сопутствующей соматической патологии, остаются актуальной нерешенной проблемой современной стоматологии.

Цель работы. Охарактеризовать изменения микрофлоры пародонтальных карманов после комплексного лечения табакозависимых пациентов с хроническим генерализованным пародонтитом на фоне хронического гиперацидного гастрита.

Материалы и методы. Было обследовано 90 пацииентов (мужчин и женщин) в возрасте от 25 до 44 лет, которые были разделены на 3 группь: первая группа - 48 пациентов с хроническим генерализованным пародонтитом (ХГП) на фоне хронического гиперацидного гастрита (ХГГ), ассоичированного с Helicobacter pylori, со стажем курения 5-7 лет и количеством выкуренных сигарет от 15 до 20 в сутки; вторая группа - 22 пацичента, больных ХГП и ХГГ, aсcоциированным с Helicobacter pylori, но без вредной привычки; третья группа - контрольная, состояла из 20 здоровых лии.

Курящчие пациенты были рандомно распределены на две подгруппь в зависимости от предложенной схемы лечения: пациентам первой подгруппы (1.1) была применена базовая терапия ХГП и предложенный лечебно-профилактический комплекс (ЛПК) (прочедуры ультрафонофореза с разработанным гелем «Аписан», 
пробиотический препарат местного применения БиоГая ПроДентис и ангиопротекторный препарат - Детралекс); пациентам второй подгруппь (1.2) применяли базовую терапию заболеваний пародонта и прочедуры ультрафонофорезу с плацебо. С иелью оченки микробиоченоза пародонтальных и десневых карманов было проведено молекулярно-генетическое исследование количественного определения пародонтопатогенов и качественного определения орального Helicobacter pylori.

Результаты исследования. Применение лечебнопрофилактического комплекса у табакозависимых пациентов и пачиентов без вредной привычки с ХГП и ХГГ, ассочиированного с Helicobacter pylori, показало положительную количественную и видовую редукцию пародонтопатогенных микроорганизмов, а также уменьшение распространенности оральной инфекции Helicobacter pylori y данной категории больных.

Вывод. Полученные результаты ПЦР-анализа после лечения позволили установить эффективность ЛПК у табакозависимых пациентов и пациентов, которые не курят, больных ХГП начального, I степени на фоне кислотозависимых заболеваний желудка. Предложенный ЛПК продемонстрировал элиминационные свойства по отношению $\kappa$ пародонтопатогенным бактериям и оральному Helicobacter pylori, что позволяет нам рекомендовать ЛПК для использования в комплексном лечении ХГП на фоне факторов риска.

Ключевые слова: пародонтит, пародонтопатогень, гастрит, табакокурение.

\section{O.L. Zolotukhina, Iu. G. Romanova S.A.Schneider}

Odessa National Medical University

State Establishment «The Institute of Stomatology and Maxillo-Facial Surgery National Academy of Medical Science of Ukraine»

\section{CHARACTERISTICS OF CHANGES IN THE MICROFLORA OF PERIODONTAL POCKETS AFTER COMPLEX TREATMENT OF TOBACCO-DEPENDENT PATIENTS WITH CHRONIC GENERALIZED PERIODONTIS ON THE BACKGROUND OF CHRONIC HYPERACID GASTRITIS}

\section{ABSTRACT}

Today, inflammatory and dystrophic periodontal diseases, which develop against the background of risk factors and concomitant somatic pathology, remain an urgent unresolved problem of modern dentistry.

The aim of the work is to characterize the changes in the microflora of periodontal pockets after complex treatment of smoking patients with chronic generalized periodontitis on the background of chronic hyperacid gastritis.

Materials and methods. 90 patients aged 25 to 44 years old were studied and divided into 3 groups: $1^{\text {st }}-48$ patients with CHGP and chronic hyperacid gastritis (CHHG) associated with Helicobacter pylori, with a smoking history of 5-7 years and the number of cigarettes smoked from 15 to 20 per day; $2^{\text {nd }}-22$ patients with CHGP and CHHG associated with Helicobacter pylori, but without the bad habit of smoking; $3^{\text {rd }}$ - control group consisted of 20 healthy individuals. Smoking patients were randomly divided into two groups depending on the chosen method of treatment: the 1st subgroup - the use of basic therapy of CHGP and developed treatment prevention complex - TPC (ultraphonophoresis procedures with the created gel "Apisan", and probiotic drug BioGaia ProDentis and angioprotective drug - Detralex); the 2nd subgroup - the use of basic therapy of CHGP and ultraphonophoresis procedures with placebo. In order to assess the microbiocenosis of periodontal and gingival pockets, a molecular genetic study of quantitative determination of periodontopathogens and qualitative determination of oral Helicobacter pylori was performed.

The results of the study. The use of a treatment-andprophylactic complex in tobacco-dependent patients and patients without a bad habit with CHGP and CHHG associated with Helicobacter pylori has shown a positive quantitative and species reduction of periodontal pathogens, as well as a reduction in the prevalence of oral Helicobacter pylori infection.

Conclusion. The results of PCR analysis after treatment allowed to establish the effectiveness of TPC in smoking patients and patients without a bad habit, with CHGP on the background of acid-dependent diseases of the stomach. The proposed TPC has demonstrated elimination properties against periodontopathogenic bacteria and oral Helicobacter pylori, which allows us to recommend TPC for use in the complex treatment of CHGP against the background of risk factors.

Key words: periodontitis, periodontopathogens, gastritis, smoking.

На сьогоднішній день запально-дистрофічні захворювання пародонта залишаються актуальною невирішеною проблемою сучасної стоматології. Як відомо, пародонтальну патологію слід розглядати з точки зору мультифакторності [1]. Серед факторів ризику розвитку захворювань тканин пародонта тютюнопаління виступає найбільш поширеним [2]. Хронічний генералізований пародонтит (ХГП) часто поєднується із захворюваннями шлунково-кишкового тракту (ШКТ) [3]. Провідним етіологічним чинником розвитку захворювань пародонта $є$ пародонтопатогенні мікроорганізми, які реалізують патогенний вплив за умов превалювання можливостей патогенних бактерій над резистентністю тканин при зниженій реактивності макроорганізму [4-5].

Мета роботи. Охарактеризувати зміни мікрофлори пародонтальних кишень після комплексного лікування тютюнозалежних пацієнтів 3 хронічним генералізованим пародонтитом на тлі хронічного гіперацидного гастриту.

Матеріали і методи дослідження. Було обстежено 90 пацієнтів (чоловіків і жінок) віком від 25 до 44 років, які були розподілені на 3 групи. Перша (основна) група складалася з 48 пацієнтів, хворих на ХГП початкового, І ступеня на 
тлі хронічного гіперацидного гастриту (ХГГ), асоційованого з Helicobacter pylori, зі стажем тютюнопаління 5-7 років і кількістю викурених цигарок від 15 до 20 на добу. Друга група (група порівняння) включала 22 пацієнта, які хворі на ХГП початкового, І ступеня та мають в анамнезі супутній ХГГ, асоційований з Helicobacter pylori, але без шкідливої звички - тютюнопаління. Третю (контрольну) групу склали 20 здорових осіб, які не мали у анамнезі патології порожнини рота, супутніх соматичних захворювань й шкідливих звичок. Усі пацієнти мали підтвердження діагнозу супутньої патології у лікаря-гастроентеролога за допомогою відеофіброгастроскопії (апарат «Olympus» GIF- 160). Постановку діагнозу ХГП здійснювали на підставі клінічних досліджень, відповідно до систематики хвороб пародонту Н.Ф. Данилевського (1994) [6].

На другому етапі дослідження пацієнти основної групи були рандомно розподілені на дві підгрупи в залежності від запропонованої схеми лікування. Пацієнтам першої підгрупи (Г1.1) була застосована базова терапія ХГП та запропонований лікувально-профілактичний комплекс (ЛПК): 10 процедур ультрафонофорезу (апарат ультразвукової терапії «УЗТ-1.02 С» 3 комплектом випромінювачів ультразвукових терапевтичних апаратів «ВУТ 0,88 - 1.03 Ф» (для стоматології), ВАТ «ЭМА», м. Москва, Росія) через день 3 розробленим гелем «Апісан» у кількості 0,050,2 г [7], аплікації гелем «Апісан» у кількості 0,05-0,2 г на уражені ділянки ясен в домашніх умовах (2 рази на добу після прийому їжі та гігієнічних заходів порожнини рота, експозицією 15 хвилин), пробіотичний препарат місцевого застосування - БіоГая ПроДентіс (по 1 пастилці 2 рази на добу: 1-ша пастилка після сніданку та гігієнічних заходів, друга пастилка перед сном) та ангіопротекторний препарат природного походження - Детралекс (по 1 таблетці 100мг 1 раз на добу 6 місяців). Дану схему лікування застосовували також у пацієнтів групи порівняння 3 метою визначення ефективності запропонованого ЛПК хворих з ХГП на тлі ХГГ без наявності фактору ризику - тютюнопаління. Профілактичний курс для даної категорії хворих являв собою режим прийому комплексу препаратів в режимі лікування. Пацієнтам другої підгрупи (1.2) застосовували базову терапію захворювань пародонта та 10 процедур ультрафонофорезу 3 плацебо через день. Також хворі на ХГГ отримували загальну антихелікобактерну терапію призначену лікаремгастроентерологом.

3 метою оцінки стану мікробіоценозу були проведені молекулярно-генетичні дослідження вмісту пародонтальних і ясенних кишень, який збирали натще серце, до ранкової гігієни ротової порожнини за допомогою стерильних паперових ендодонтичних штифтів (розмір №25), які вводили пінцетом у найбільш глибокі ділянки кишені на 15 секунд. Після забору матеріал негайно поміщався в стерильні герметичні пробірки типу Eppendorf (1,5 мл) з 1 мл фізіологічного розчину для транспортування в лабораторію в спеціальному термоконтейнері 3 хладагентом. За допомогою набору «Дентоскрин для количественного анализа формата Флуоропол-РВ» ((Комплектация OneStep Strip) НПФ «Литех», Россия) для полімеразної ланцюгової реакції (ПЛР) проводили кількісне визначення пародонтопатогенів: Aggregatibacter actinomycetemcomitans (Aa), Tannerella forsythia (Tf), Treponema denticola (Td), Prevotella intermedia (Pi), Fusobacterium nucleatum (Fn), Porphyromonas gingivalis $(P g)$ та Porphyromonas endodontalis $(\mathrm{Pe})$ за стандартною методикою на ампліфікаторі CFX96 Touch «REAL TIME» (Bio-Rad, CШA). За допомогою набору «Хеликопол для качественного анализа формата Флуоропол-РВ» ((Комплектация OneStep Strip) НПФ «Литех», Россия) для ПЛР проводили якісне визначення інфекції Helicobacter pylori згідно з відповідною інструкцією за стандартною методикою. Дослідження проводили до та після лікування.

Результати дослідження та їх обговорення. ПЛР-аналіз досліджуваних зразків вмісту пародонтальних кишень тютюнозалежних пацієнтів основної групи з ХГП на тлі ХГГ показав, що всі 7 досліджених пародонтопатогенів були присутні в тому чи іншому відсотку випадків, при цьому одночасно були виявлені усі представники «червоного комплексу», які володіють найвищою пародонтопатогенністю. У 100\% випадків були виявлені патогени Prevotella intermedia та Porphyromonas endodontalis. У пацієнтів групи порівняння були виявлені практично всі представники пародонтопатогенних мікроорганізмів, але значно нижчої концентрації у порівнянні з основною групою, окрім Tannerella forsythia, яка не була виявлена в жодному з випадків групи порівняння. 3 іншого боку, ПЛР-аналіз зразків контрольної групи показали наявність патогенів Tannerella forsythia, Treponema denticola, Prevotella intermedia, Fusobacterium nucleatum та Porphyromonas endodontalis у незначній концентрації у порівнянні зі зразками основної групи та групи порівняння (табл. 1). Наявність пародонтопатогенів у соматично здорових осіб з інтактним пародонтом ймовірно не активує патологічний процес завдяки відсутності впливу факторів ризику і соматичної патології, нормальному стану місцевої резистентності тканин та превалюванню представників нормальної мікрофлори ротової порожнини. 
Після застосування запропонованого ЛПК у пацієнтів підгрупи 1.1 та групи порівняння значно змінюється кількісний склад мікробіоценозу пародонтальних кишень. У хворих зменшується кількість та процент виявлення пародонтопатогенів - Tannerella forsythia, Porphyromonas endodontalis та Porphyromonas gingivalis. У пацієнтів підгрупи 1.1, яким застосовували ЛПК, була досягнута повна елімінація патогенних бактерій - Prevotella intermedia, Fusobacterium nucleatum та зменшення кількості патогенів Tannerella forsythia, Porphyromonas endodontalis та Porphyromonas gingivalis. Проте, визначалося зростання кількості патогена Treponema denticola у порівнянні з показниками до лікування, що можливо обумовлено відсутністю специфічності антибактеріальної дії ЛПК. ПЛР-аналіз мікробіоценозу пародонтальних кишень хворих підгрупи 1.2 , яким було під час лікування не застосовували запропонований ЛПК, продемонстрував зростання після лікування кількісного вмісту патогенних форм, що пояснюється відсутністю антибактеріальної та пробіотичної дії застосованих лікувальних заходів. Навпаки, у пацієнтів групи порівняння після отримання запропонованого лікування досягнута повна елімінація практично усіх пародонтопатогенів, окрім Porphyromonas endodontalis та Treponema denticola на тлі зниження їх кількісного складу (табл. 2).

Таблиця 1

Якісний і кількісний склад пародонтопатогенів в ясенних і пародонтальних кишенях паціснтів груп дослідження до лікування

\begin{tabular}{|c|c|c|c|c|c|c|}
\hline \multirow{3}{*}{$\begin{array}{c}\text { Мікрорганізми } \\
\text { (пародонтопатогени) }\end{array}$} & \multicolumn{6}{|c|}{ Досліджувані групи пацієнтів } \\
\hline & \multicolumn{2}{|c|}{$\begin{array}{c}\text { контрольна група }- \text { ГК, } \\
\mathrm{n}=20\end{array}$} & \multicolumn{2}{|c|}{$\begin{array}{c}\text { група порівняння }- \text { Г2, } \\
\mathrm{n}=22\end{array}$} & \multicolumn{2}{|c|}{ основна група $-\Gamma 1, \mathrm{n}=48$} \\
\hline & $\begin{array}{c}\text { Кіл-сть } \times 10^{3}, \\
\mathrm{M} \pm \mathrm{m}\end{array}$ & $\begin{array}{l}\% \text { ви- } \\
\text { явл. }\end{array}$ & $\begin{array}{c}\text { Кіл-сть } \times 10^{3}, \\
\mathrm{M} \pm \mathrm{m}\end{array}$ & \% виявл. & $\begin{array}{c}\text { Кіл-сть } \times 10^{3}, \\
\mathrm{M} \pm \mathrm{m}\end{array}$ & $\%$ виявл. \\
\hline $\begin{array}{l}\text { Aggregatibacter } \\
\text { actinomycetemcomitans }\end{array}$ & 0 & 0 & $0,42 \pm 0,19$ & 27,3 & $2,81 \pm 1,47$ & 12,5 \\
\hline Tannerella forsythia & $0,26 \pm 0,16$ & 20,0 & 0 & 0 & $2,92 \pm 0,77$ & 75,0 \\
\hline Treponema denticola, & $2,66 \pm 2,17$ & 35,0 & $0,05 \pm 0,03$ & 31,8 & $121,59 \pm 29,16$ & 83,3 \\
\hline Prevotella intermedia & $11,89 \pm 7,23$ & 30,0 & $916,52 \pm 309,01$ & 100,0 & $\begin{array}{c}1388,71 \pm \\
307,98\end{array}$ & 100,0 \\
\hline Fusobacterium nucleatum & $8,96 \pm 4,96$ & 40,0 & $22,29 \pm 4,69$ & 100,0 & $365,07 \pm 99,36$ & 85,4 \\
\hline Porphyromonas gingivalis & 0 & 0 & $71,07 \pm 23,91$ & 90,9 & $47,71 \pm 22,99$ & 31,3 \\
\hline $\begin{array}{l}\text { Porphyromonas } \\
\text { endodontalis }\end{array}$ & $\begin{array}{c}9575000000,37 \pm \\
4113568023,71\end{array}$ & 65,0 & $\begin{array}{l}2094400000,32 \\
\pm 747359420,37\end{array}$ & 100,0 & $\begin{array}{c}3057953349233 \\
03,00 \pm 1481866 \\
94218187,00\end{array}$ & 100,0 \\
\hline
\end{tabular}

Таблиця 2

Характеристика мікробіоценозу пародонтальних кишень до та після лікування пацієнтів груп дослідження

\begin{tabular}{|c|c|c|c|c|}
\hline \multirow{3}{*}{$\begin{array}{c}\text { Мікрорганізми } \\
\text { (пародонтопатогени) }\end{array}$} & \multicolumn{4}{|c|}{ Підгрупа 1.1, n=24 } \\
\hline & \multicolumn{2}{|c|}{ До лікування } & \multicolumn{2}{|c|}{ Після лікування } \\
\hline & кіл-сть $\times 10^{3}, \mathrm{M} \pm \mathrm{m}$ & \% виявлення & кіл-сть $\times 10^{3}, \mathrm{M} \pm \mathrm{m}$ & \% виявлення \\
\hline 1 & 2 & 3 & 4 & 5 \\
\hline $\begin{array}{l}\text { Aggregatibacter } \\
\text { actinomycetemcomitans }\end{array}$ & 0 & 0 & 0 & 0 \\
\hline Tannerella forsythia & $1,3 \pm 0,3$ & 83,3 & $0,38 \pm 0,18$ & 25,0 \\
\hline Treponema denticola & $178,86 \pm 51,78$ & 83,3 & $58431,32 \pm 32923,06$ & 100,0 \\
\hline Prevotella intermedia & $1051,57 \pm 230,48$ & 100,0 & 0 & 0 \\
\hline Fusobacterium nucleatum & $472,70 \pm 165,15$ & 100,0 & 0 & 0 \\
\hline Porphyromonas gingivalis & $0,14 \pm 0,45$ & 41,7 & $0,001 \pm 0,0007$ & 20,8 \\
\hline $\begin{array}{l}\text { Porphyromonas } \\
\text { endodontalis }\end{array}$ & $\begin{array}{c}610003274093352,00 \\
\pm 285829929129886,00\end{array}$ & 100,0 & $12887,37 \pm 4776,25$ & 50,0 \\
\hline
\end{tabular}


Продовження таблиці 2

\begin{tabular}{|c|c|c|c|c|}
\hline 1 & 2 & 3 & 4 & 5 \\
\hline \multirow{3}{*}{$\begin{array}{l}\text { Мікрорганізми } \\
\text { (пародонтопатогени) }\end{array}$} & \multicolumn{4}{|c|}{ Підгрупа 1.2, n=24 } \\
\hline & \multicolumn{2}{|c|}{ До лікування } & \multicolumn{2}{|c|}{ Після лікування } \\
\hline & кіл-сть $\times 10^{3}, \mathrm{M} \pm \mathrm{m}$ & \% виявлення & кіл-сть $\times 10^{3}, \mathrm{M} \pm \mathrm{m}$ & \% виявлення \\
\hline $\begin{array}{l}\text { Aggregatibacter } \\
\text { actinomycetemcomitans }\end{array}$ & $5,63 \pm 2,86$ & 25,0 & $5,90 \pm 3,13$ & 16,7 \\
\hline Tannerella forsythia & $4,55 \pm 1,45$ & 66,7 & $751,62 \pm 185,30$ & 100,0 \\
\hline Treponema denticola & $64,31 \pm 22,56$ & 83,3 & $132,17 \pm 40,97$ & 100,0 \\
\hline Prevotella intermedia & $1725,84 \pm 569,78$ & 100,0 & $188,60 \pm 104,77$ & 16,7 \\
\hline Fusobacterium nucleatum & $257,43 \pm 109,85$ & 70,8 & $252,58 \pm 94,96$ & 70,8 \\
\hline Porphyromonas gingivalis & $95,29 \pm 44,32$ & 20,8 & $55,72 \pm 22,15$ & 45,8 \\
\hline $\begin{array}{l}\text { Porphyromonas } \\
\text { endodontalis }\end{array}$ & $\begin{array}{l}1587395753253,86 \\
\pm 877319937475,53 \\
\end{array}$ & 100,0 & $476,05 \pm 212,45$ & 100,0 \\
\hline \multirow{3}{*}{$\begin{array}{l}\text { Мікрорганізми } \\
\text { (пародонтопатогени) }\end{array}$} & \multicolumn{4}{|c|}{ Група порівняння, $\mathrm{n}=22$} \\
\hline & \multicolumn{2}{|c|}{ До лікування } & \multicolumn{2}{|c|}{ Після лікування } \\
\hline & кіл-сть $\times 10^{3}, \mathrm{M} \pm \mathrm{m}$ & \% виявлення & кіл-сть $\times 10^{3}, \mathrm{M} \pm \mathrm{m}$ & \% виявлення \\
\hline $\begin{array}{l}\text { Aggregatibacter } \\
\text { actinomycetemcomitans }\end{array}$ & $0,42 \pm 0,19$ & 27,3 & 0 & 0 \\
\hline Tannerella forsythia & 0 & 0 & 0 & 0 \\
\hline Treponema denticola & $0,05 \pm 0,03$ & 31,8 & $0,037 \pm 0,016$ & 40,9 \\
\hline Prevotella intermedia & $916,52 \pm 309,01$ & 100,0 & 0 & 0 \\
\hline Fusobacterium nucleatum & $22,29 \pm 4,69$ & 100,0 & 0 & 0 \\
\hline Porphyromonas gingivalis & $71,07 \pm 23,91$ & 90,9 & 0 & 0 \\
\hline $\begin{array}{l}\text { Porphyromonas } \\
\text { endodontalis }\end{array}$ & $\begin{array}{c}2094400000,32 \pm \\
747359420,37\end{array}$ & 100,0 & $9700,27 \pm 6151,35$ & 40,9 \\
\hline
\end{tabular}

За ПЛР-аналізом оральний Helicobacter pylori був виявлений у пацієнтів основної групи i групи порівняння із ХГГ, асоційованим 3 Helicobacter pylori, а також у соматично здорових пацієнтів контрольної групи, що підтверджує дані наукової літератури щодо сприймання ротової порожнини як вторинного резервуару бактеpiï. Найбільша поширеність орального
Helicobacter pylori спостерігається у тютюнозалежних пацієнтів з ХГП на тлі ХГГ, що може бути обумовлено збільшеною персистенцією бактерії у ротовій порожнині за умов поєднаного впливу фактору ризику - тютюнопаління та супутньої патології ШКТ, асоційованих 3 даною інфекцією (табл. 3).

Таблиця 3

Поширеність Helicobacter pylori за даними ПЛР-аналізу у паціснтів груп дослідження

\begin{tabular}{|c|c|c|c|c|c|c|c|}
\hline \multirow{3}{*}{$\begin{array}{c}\text { Результат } \\
\text { ПЛР-аналізу }\end{array}$} & \multicolumn{7}{|c|}{ Досліджувані групи пацієнтів, n=90 } \\
\hline & \multirow{2}{*}{$\begin{array}{c}\text { Контрольна гру- } \\
\text { па, } \mathrm{n}=20\end{array}$} & \multicolumn{2}{|c|}{ Група порівняння, $\mathrm{n}=22$} & \multicolumn{2}{|c|}{ Підгрупа $1.1, \mathrm{n}=24$} & \multicolumn{2}{|c|}{ Підгрупа $1.2, \mathrm{n}=24$} \\
\hline & & $\begin{array}{c}\text { до ліку- } \\
\text { вання }\end{array}$ & $\begin{array}{c}\text { після ліку- } \\
\text { вання }\end{array}$ & $\begin{array}{c}\text { до ліку- } \\
\text { вання }\end{array}$ & $\begin{array}{c}\text { після ліку- } \\
\text { вання }\end{array}$ & $\begin{array}{c}\text { до ліку- } \\
\text { вання }\end{array}$ & $\begin{array}{c}\text { після ліку- } \\
\text { вання }\end{array}$ \\
\hline $\begin{array}{l}\text { Позитивна } \\
\text { реакція, } \\
\text { абс (\%) }\end{array}$ & $4(20,0 \%)$ & $\begin{array}{c}12 \\
(54,5 \%)\end{array}$ & $\begin{array}{c}5 \\
(22,7 \%)\end{array}$ & $\begin{array}{c}14 \\
(58,3 \%)\end{array}$ & $\begin{array}{c}6 \\
(25,0 \%)\end{array}$ & $\begin{array}{c}16 \\
(66,7 \%)\end{array}$ & $\begin{array}{c}9 \\
(37,5 \%)\end{array}$ \\
\hline $\begin{array}{l}\text { Негативна } \\
\text { реакція, } \\
\text { абс }(\%)\end{array}$ & $16(80,0 \%)$ & $\begin{array}{c}10 \\
(45,5 \%)\end{array}$ & $\begin{array}{c}17 \\
(77,3 \%)\end{array}$ & $\begin{array}{c}10 \\
(41,7 \%)\end{array}$ & $\begin{array}{c}18 \\
(75,0 \%)\end{array}$ & $\begin{array}{c}8 \\
(33,3 \%)\end{array}$ & $\begin{array}{c}15 \\
(62,5 \%)\end{array}$ \\
\hline
\end{tabular}

Оцінка результатів ПЛР-аналізу поширеності Helicobacter pylori у вмісті пародонтальних карманів після застосування ЛПК показала позитивну редукцію показників. Найкращі результати були виявлені у пацієнтів групи порівняння: позитивна реакція була виявлена лише у 22,7 \% осіб, що обумовлено відсутністю шкідливого впливу тютюнопаління. У пацієнтів підгрупи 1.1, яким застосовували ЛПК, позитивна реакція була виявлена у 25,0\% осіб. Найгірші показники були реєстровані у пацієнтів підгрупи 1.2, яким застосовували процедури ультрафонофорезу 3 плацебо: позитивна реакція була виявлена у $37,5 \%$ осіб (табл. 3).

Висновки. Таким чином, застосування розробленого ЛПК у тютюнозалежних пацієнтів та пацієнтів, які не палять, 3 ХГП початкового, I ступеня на тлі кислотозалежних захворювань шлунку - ХГГ, асоційованого з H. pylori, вияви- 
лося ефективним щодо елімінації пародонтопатогенних бактерій та оральної інфекції H.pylori.

\section{Список літератури}

1. Подгаецкая О.Е. Этиология и патогенез хронического генерализованного пародонтита / О.Е. Подгаецкая // Буковинський медичний вісник. - 2007. - №1. - С.127.

2. Ільчишин М.П. Поширеність захворювань пародонту серед тютюнозалежних осіб / М.П. Ільчишин, А.І. Фурдичко, А.Я. Бариляк // Новини стоматології. - 2018. №4(97). - C.86-88.

3. Ярова С. П. Особенности распространения и течения воспалительно-дистрофических процессов в пародонте на фоне заболеваний желудочно-кишечного тракта / С. П. Ярова, В. С. Алексеева // Український стоматологічний альманах. - 2014. - № 2. - С. 105-107.

4. Савичук Н. О. Колонізаційна резистентність порожнини рота / Н. О. Савичук // Український медичний часопис. -2012 . - № 4. - С. 57-63.

5. Socransky SS. Microbial complexes in subgingival plaque / Socransky SS., Haffajee AD., Cugini MA., Smith C., Kent Jr. RL. // Journal of Clinical Periodontology. - 1998. №25. - P.134-144.

6. Данилевський Н.Ф. Заболевания пародонта / Н.Ф. Данилевський, А.В. Борисенко. - К.: Здоров'я, 2000. - 462 с.

7. Патент на корисну модель України №119715 МПК (2017.01) А61К36/00 Гель «Апісан» для місцевого лікування та профілактики травматичних уражень слизової оболонки порожнини рота / Кравченко Л.С. заявник і патентовласник
Одеський національний медичний університет. №u201702228 від 10.03.2017. - 2017. - Бюл. №19.

\section{REFERENCES}

1. Podhaetskaya O.E. Etiology and pathogenesis of chronic generalized periodontitis. Bukovynskyi medychnyi visnyk. 2007; 1: 127.

2. Ilchyshyn M.P., Furdychko A.I., Barylyak A.Ya. Prevalence of periodontal diseases among tobacco addicts. Novyny stomatologiyi. 2018; 4 (97): 86-8.

3. Yarova S.P., Alekseeva V.S. Features of the spread and course of inflammatory and dystrophic processes in the periodontium against the background of diseases of the gastrointestinal tract. Ukrayins `kij stomatologi`chnij al ’manakh. 2014; 2: 105-7.

4. Savichuk NO. Colonization resistance of the oral cavity. Sovremennaya stomatologiya. 2011;(3):87-91.

5. Socransky SS., Haffajee AD., Cugini MA., Smith C., Kent Jr. RL. Microbial complexes in subgingival plaque. Journal of Clinical Periodontology. 1998; 25: 134-144.

6. Danilevskiy N.F., Borisenko A.V. Zabolevaniya parodonta [Periodontal diseases]. Kyyiv: Zdorov'ya, 2000:462.

7. Kravchenko L.S. Patent na korysnu model Ukrainy №119715 MPK (2017.01) A61K36/00 Hel «Apisan» dlia mistsevoho likuvannia ta profilaktyky travmatychnykh urazhen slyzovoi obolonky porozhnyny rota zaiavnyk i patentovlasnyk Odeskyi natsionalnyi medychnyi universytet. №u201702228 vid 10.03.2017. 2017. Biul. №19. 